Article

\title{
Synthesis of high-surface-area Co-0-Si complex oxide for skeletal isomerization of 1-hexene and hydrodesulfurization of thiophene
}

\author{
Yu Zhao, Jun'en Wang, Hui Chen, Xiaoyan Zhang, Yuchuan Fu\#, Jianyi Shen* \\ Lab of Mesoscopic Chemistry, School of Chemistry and Chemical Engineering, Nanjing University, Nanjing 210093, Jiangsu, China
}

\section{A R T I C L E I N F O}

Article history:

Received 19 January 2014

Accepted 10 March 2014

Published 20 August 2014

Keywords:

Co-O-Si complex oxide

Surface acidity

Hydrogenation

Skeletal isomerization

Hydrodesulfurization

\begin{abstract}
A B S T R A C T
The coprecipitation of sodium silicate with cobalt nitrate, combined with an $n$-butanol drying process, led to the formation of a Co-O-Si complex oxide (Co/Si atomic ratio $\approx 0.65$ ) with atomically dispersed Co and Si atoms. The complex oxide had a high surface area $\left(562 \mathrm{~m}^{2} / \mathrm{g}\right)$ and strong surface acidity. Sulfidation resulted in the formation of highly dispersed cobalt sulfide, which had high activity in the hydrodesulfurization (HDS) of thiophene (99.4\%) and skeletal isomerization of 1-hexene (35\%) at $573 \mathrm{~K}$. The HDS activity was as high as that of the industrial catalyst $\mathrm{Co}-\mathrm{Mo} / \gamma-\mathrm{Al}_{2} \mathrm{O}_{3}$, although no Mo was present. The material could therefore be used for the skeletal isomerization of linear olefins during deep HDS of gasoline to reduce octane number loss caused by olefin saturation.
\end{abstract}

(C) 2014, Dalian Institute of Chemical Physics, Chinese Academy of Sciences. Published by Elsevier B.V. All rights reserved.

\section{Introduction}

Gasoline consumption is increasing annually, and the legislative restrictions regarding quality are becoming more severe. It is necessary not only to decrease the sulfur content greatly, but also to restrict the olefin content of gasoline. A high olefin content may increase the emission of particulate matter from automobiles, and cause environmental pollution [1]. Naphtha obtained by fluid catalytic cracking contains about $70 \mathrm{wt} \%$ $\mathrm{C}_{5}-\mathrm{C}_{7}$ olefins, which are mainly present in linear and monosubstituted forms [2]. The hydrogenation of these olefins to the corresponding normal alkanes during hydrodesulfurization (HDS) significantly decreases the gasoline octane number (for example, the octane number of 1-hexene is 76, whereas that of $n$-hexane is only 26). An alternative way to solve this problem is skeletal isomerization of linear olefins to branched ones, followed by hydrogenation to isoalkanes with high octane numbers (for example, the octane number of 2,2-dimethylbutane is 92). However, it is usually difficult for catalysts to exhibit excellent activities for HDS and skeletal isomerization of olefins simultaneously. Industrially, olefins are usually saturated during deep HDS, and alkylation and isomerization are performed with other catalysts to redeem the octane number losses during HDS [3]. It is therefore important to develop catalysts that exhibit excellent activities for HDS and skeletal isomerization of olefins simultaneously. If this is achieved, the two processes can be performed in one step, significantly reducing the operating costs.

The skeletal isomerization of olefins itself is also important in petroleum industries. For example, isopentene and isobutene are the raw materials for the production of tert-amyl methyl ether and methyl tert-butyl ether, respectively, which are widely used as additives for improving the quality and octane number of gasoline [4]. These two olefins are mainly produced

\footnotetext{
* Corresponding author. Tel/Fax: +86-25-83594305; E-mail: jyshen@nju.edu.cn

\# Corresponding author. Tel: +86-25-83594305; E-mail: ycfu@nju.edu.cn

This work was supported by the National Natural Science Foundation of China (21273105, 21073089), the Ministry of Science and Technology Innovation Fund (2013AA031703), and the Fundamental Research Funds for the Central Universities (1084020501).

DOI: 10.1016/S1872-2067(14)60074-7 | http://www.sciencedirect.com/science/journal/18722067 | Chin. J. Catal., Vol. 35, No. 8, August 2014
} 
industrially by skeletal isomerization of the corresponding linear olefins $[5,6]$. The hydration of olefins to the corresponding alcohols is another field that attracts the attention of both industry and academia [7], but the hydration of linear olefins is much more difficult than that of the branched ones containing tertiary carbons [8]. The skeletal isomerization of linear olefins to branched ones is therefore an important process.

The mechanism of skeletal isomerization of a linear olefin to a branched one involves adsorption of the linear olefin on a Brønsted acid site to form a carbenium cation intermediate, followed by rearrangement of the skeletal carbon atoms [9]. Other catalytic systems for the skeletal isomerization of olefins include zeolites (e.g., SAPO-11 [10], MCM-41 [11], $\beta$-zeolites [12], and HFER zeolites [13]), Pt supported on sulfated or tungstated zirconia [14], and sulfated mesoporous transition-metal oxides [15,16]. Shi et al. [17] found that Co-MCM-41 catalysts exhibited good activities for the skeletal isomerization of 1-hexene during HDS. However, MCM-41-type materials are expensive, because they are synthesized using templating agents [18]. Co-Si-O mixed oxides could therefore act as substitutes. The preparation of Co-Si-O mixed oxides has been reported in the literature. Methods such as sol-gel [19] and hydrothermal syntheses [20] have been used. Tetraethoxysilane is usually used as the silica source for the preparation of nanomaterials with special morphologies. In our current work, cheap $\mathrm{Na}_{2} \mathrm{SiO}_{3}$ was used as the silica source, and a simple coprecipitation method combined with an $n$-butanol drying process was used to prepare Co-Si-O mixed oxides. The surface areas were high, even for mixed oxides with high Co contents. In addition, these materials had large pores and pore volumes, and could be used as catalysts and catalyst supports.

\section{Experimental}

\subsection{Catalyst preparation}

Co-Si-O mixed oxides with different $\mathrm{Co} / \mathrm{Si}$ atomic ratios were prepared by coprecipitation. In a typical synthesis of Co-Si-O with a nominal Co/Si ratio of $1, \mathrm{Co}\left(\mathrm{NO}_{3}\right)_{2} \cdot 6 \mathrm{H}_{2} \mathrm{O}(29.1 \mathrm{~g}$, $0.1 \mathrm{~mol})$ was dissolved in an aqueous solution of $\mathrm{HNO}_{3}$ (1.8 mol/L, $100 \mathrm{~mL}$ ). $\mathrm{Na}_{2} \mathrm{SiO}_{3} \cdot 9 \mathrm{H}_{2} \mathrm{O}(28.4 \mathrm{~g}, 0.1 \mathrm{~mol})$ was dissolved in deionized water $(10 \mathrm{~mL})$. The two solutions were added dropwise to deionized water (400 mL) under stirring at $363 \mathrm{~K}$, during which a purple precipitate formed. After stirring for another $0.5 \mathrm{~h}$, the mixture was sealed, using a plastic film, in the beaker and aged at $363 \mathrm{~K}$ for $12 \mathrm{~h}$ without stirring. The precipitate was filtered and washed thoroughly with deionized water. It was then added to $n$-butanol $(200 \mathrm{~mL})$ and heated at $353 \mathrm{~K}$, during which the water evaporated with the $n$-butanol. It was further dried at $393 \mathrm{~K}$ for $12 \mathrm{~h}$. The obtained solid sample was calcined at $673 \mathrm{~K}$ for $3 \mathrm{~h}$, and denoted by CS10. Other samples with nominal $\mathrm{Co} / \mathrm{Si}$ ratios of $0.1,0.2$, and 0.4 were prepared in the same way, and denoted by CS1, CS2, and CS4, respectively.

For comparison, a $\mathrm{CoO}_{x} / \mathrm{SiO}_{2}$ sample (denoted by I-CS10) was prepared using an impregnation method; it contained the same amount of Co as CS10. Commercial $\mathrm{SiO}_{2}\left(504 \mathrm{~m}^{2} / \mathrm{g}\right)$ was used as the support. After drying at $393 \mathrm{~K}$, the sample was cal- cined at $673 \mathrm{~K}$ for $3 \mathrm{~h}$.

\subsection{Catalyst characterization}

$\mathrm{N}_{2}$ adsorption-desorption measurements were carried out at $77 \mathrm{~K}$ using a Micromeritics Gemini V 2380 autosorption analyzer. The specific surface areas were calculated using the BET equation, and pore-size distributions were determined using the BJH method. Samples were degassed in flowing $\mathrm{N}_{2}$ at $473 \mathrm{~K}$ for $5 \mathrm{~h}$ before the measurements.

X-ray diffraction (XRD) patterns were obtained with a Shimadzu XRD-6000 powder diffractometer (Japan), using $\mathrm{Cu} \mathrm{K}_{\alpha}$ radiation $(\lambda=0.15418 \mathrm{~nm})$. The $2 \theta$ scans covered the range $10^{\circ}$ to $80^{\circ}$, with a step of $0.02^{\circ}$.

Microcalorimetric adsorption of $\mathrm{NH}_{3}$ was performed using a Setaram Tian-Calvet C-80 heat-flux microcalorimeter connected to a gas-handling system equipped with a Baratron capacitance manometer for precise pressure measurements. Samples were evacuated at $573 \mathrm{~K}$ for $3 \mathrm{~h}$ before the measurements. Microcalorimetric adsorption was performed at $423 \mathrm{~K}$.

Laser Raman spectra of the samples were obtained at room temperature in air, using an Invia Raman microscope spectrometer (Renishaw) equipped with a charge-coupled device detector. The 514.5-nm line of an $\mathrm{Ar}^{+}$laser was used as the excitation source, with $10 \mathrm{~mW}$ intensity.

Temperature programmed reduction (TPR) was performed by using a quartz U-tube reactor loaded with about $50 \mathrm{mg}$ of a sample. All samples were directly used for the TPR measurements without the further pretreatment. A mixture of $\mathrm{N}_{2}$ and $\mathrm{H}_{2}$ ( $5 \% \mathrm{H}_{2}$ by volume) was used as the reducing agent and the flow rate was maintained at $40 \mathrm{ml} / \mathrm{min}$. The hydrogen consumption was monitored using a thermal conductivity detector (TCD). The temperature was raised at a programmed rate of 10 $\mathrm{K} / \mathrm{min}$ from 285 to $1273 \mathrm{~K}$.

Transmission electron microscope (TEM) was performed using a JEOL JEM-2100 high-resolution microscope operating at $200 \mathrm{kV}$. The samples were dispersed in 5\% ethanol solution and dropped onto a copper grid coated with a carbon film. Scanning electron microscopy (SEM) images were captured using a Hitachi S-4800 field-emission microscope operated at 5 $\mathrm{kV}$.

The chemical compositions of the catalysts were determined using X-ray fluorescence (XRF) spectroscopy (ARL9800).

\subsection{Catalytic tests}

The skeletal isomerization of 1-hexene was carried out in a fixed-bed reactor. The reaction solution contained $20 \mathrm{wt} \%$ 1-hexene, 500 ppmw sulfur (thiophene), and balance heptane (solvent). Before the catalytic tests, the catalysts were sulfided with $2 \% \mathrm{CS}_{2}$ in heptane, first at $503 \mathrm{~K}$ for $2 \mathrm{~h}$ and then at $593 \mathrm{~K}$ for $4 \mathrm{~h}$. The isomerization reactions were carried out from 493 to $573 \mathrm{~K}$ at $1.5 \mathrm{MPa}$, with a liquid hourly space velocity (LHSV) of $2 \mathrm{~h}^{-1}$ and an $\mathrm{H}_{2} /$ oil ratio of $300(\mathrm{v} / \mathrm{v})$. The reaction products were analyzed using an SP-2000B gas chromatograph equipped with SE-30 capillary columns. Flame ionization and 
flame photometric detectors were used for the analysis of hydrocarbons and organic sulfur compounds, respectively.

\section{Results and discussion}

\subsection{Compositions and structures of fresh samples}

A series of samples (CS1, CS2, CS4, and CS10) with different $\mathrm{Co} / \mathrm{Si}$ nominal ratios were prepared. Figure 1 shows the XRD patterns of these samples. Samples CS1 and CS2 exhibited only a broad peak at $23.5^{\circ}$, corresponding to amorphous $\mathrm{SiO}_{2}$ [21] This broad peak was very small for CS4 and disappeared for CS10 (with a Co/Si nominal ratio of 1), indicating that almost no $\mathrm{SiO}_{2}$ clusters remained in these two samples. In addition, no diffraction peaks for Co species were observed for the samples. The Co and Si atoms were therefore homogeneously mixed in CS10. In contrast, the sample I-CS10, prepared using an impregnation method, displayed sharp diffraction peaks corresponding to crystallized $\mathrm{Co}_{3} \mathrm{O}_{4}$ (PDF 74-2120), indicating large particles of $\mathrm{Co}_{3} \mathrm{O}_{4}$ dispersed on $\mathrm{SiO}_{2}$. A broad XRD peak for $\mathrm{SiO}_{2}$ was also observed for I-CS10.

Figure 2 shows the Raman spectra of CS1, CS10, and I-CS10, and those of $\mathrm{SiO}_{2}$ and $\mathrm{Co}_{3} \mathrm{O}_{4}$, for comparison. $\mathrm{SiO}_{2}$ exhibited two sharp bands at 3080 and $1120 \mathrm{~cm}^{-1}$, and a broad band at 1020 $\mathrm{cm}^{-1} . \mathrm{Co}_{3} \mathrm{O}_{4}$ displayed three sharp bands at 685, 520, and 475 $\mathrm{cm}^{-1}$ [22]. CS1, with a nominal $\mathrm{Co} / \mathrm{Si}$ ratio of 0.1 , contained mainly $\mathrm{SiO}_{2}$ ( $\sim 90$ atom\%), with a small amount of Co $(\sim 10$ atom\%). This sample showed two sharp bands at 3080 and $1120 \mathrm{~cm}^{-1}$, and a broad band at $1020 \mathrm{~cm}^{-1}$, similar to those for $\mathrm{SiO}_{2}$. No Raman bands for $\mathrm{Co}_{3} \mathrm{O}_{4}$ were observed for CS1, indicating that the Co species were atomically dispersed in the $\mathrm{SiO}_{2}$ matrix in CS1. The Co content of CS10 was much higher than that of CS1, and only very weak Raman bands from $\mathrm{SiO}_{2}$ $\left(\sim 3080 \mathrm{~cm}^{-1}\right)$ and $\mathrm{Co}_{3} \mathrm{O}_{4}\left(\sim 680 \mathrm{~cm}^{-1}\right)$ were observed for CS10. $\mathrm{Si}$ and Co might therefore both be mainly atomically dispersed in CS10. However, a new broad band at $815 \mathrm{~cm}^{-1}$ appeared in the Raman spectrum of CS10. This band was very weak in the Raman spectrum of CS1, suggesting that it might be related to

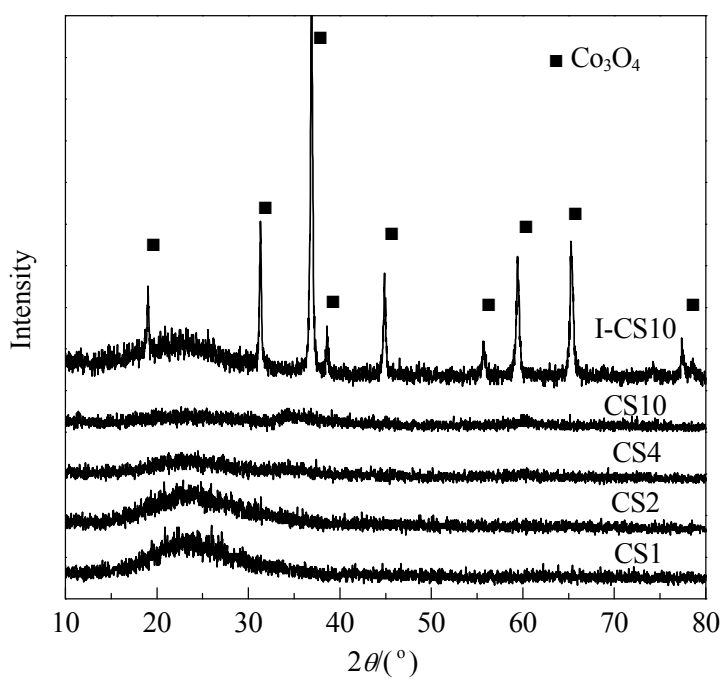

Fig. 1. XRD patterns of Co-Si-O samples after calcination at $673 \mathrm{~K}$.

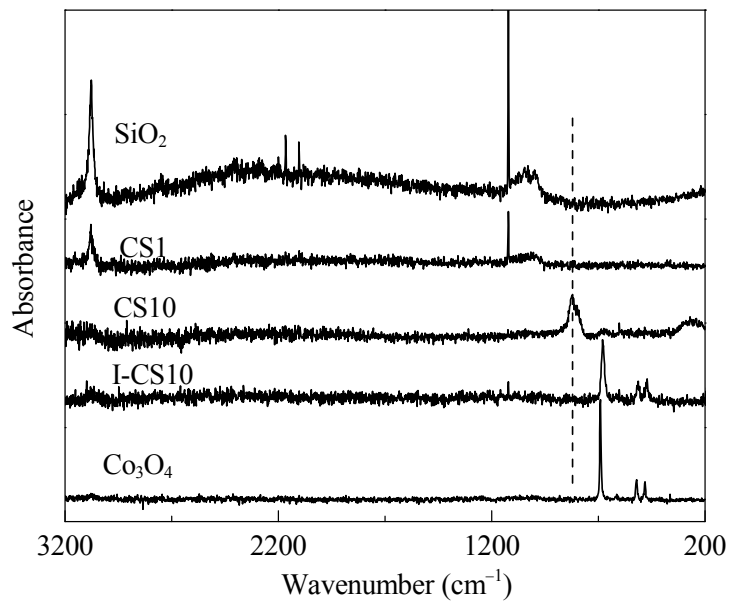

Fig. 2. Raman spectra of $\mathrm{SiO}_{2}, \mathrm{Co}_{3} \mathrm{O}_{4}$, and $\mathrm{Co}-\mathrm{Si}-\mathrm{O}$ samples after calcination at $673 \mathrm{~K}$.

some Co-O-Si clusters with concentrated cobalt cations. As expected, I-CS10 exhibited three Raman bands similar to those of $\mathrm{Co}_{3} \mathrm{O}_{4}$ [22], but these bands were broadened as a result of dispersion of $\mathrm{Co}_{3} \mathrm{O}_{4}$ on $\mathrm{SiO}_{2}$. The XRD and Raman results therefore confirmed high dispersion of Co cations in the Co-Si-O mixed oxides prepared in this work.

Further studies showed that the activities of CS1 and CS2 were low in the hydrogenation of 1-hexene. In addition, the surface area of CS4 was low compared with those of the other samples in the CS series, and it is at present difficult to explain the trends in the changes with composition in the structures, and chemical and catalytic properties for the CS series of samples. We therefore focus on CS10 in the following discussion. This sample was unique, because it had a high surface area (562 $\mathrm{m}^{2} / \mathrm{g}$, see Table 1) and atomically mixed Co-O-Si networks containing high amounts of Co ( 34 wt\%). Shi et al. [17] previously synthesized Co-MCM-41 samples, and the highest Co content in the MCM-41 framework was about $15 \mathrm{wt} \%$.

The Co contents of CS10 and I-CS10 were analyzed using $\mathrm{XRF}$, and estimated to be about 34.2 and $31.1 \mathrm{wt} \%$, corresponding to $\mathrm{Co} / \mathrm{Si}$ ratios of 0.65 and 0.56 , respectively. The $\mathrm{Co} / \mathrm{Si}$ ratio of CS10 was lower than 1 , indicating that some of the Co was not deposited during precipitation.

\subsection{Textural properties}

The BET surface areas and BJH pore-size distributions of the samples were obtained through $\mathrm{N}_{2}$ adsorption-desorption measurements at $77 \mathrm{~K}$. Table 1 summarizes the surface areas, pore volumes, and average pore diameters of CS10 and I-CS10.

Table 1

Textural properties of catalysts.

\begin{tabular}{lccc}
\hline Sample & $\begin{array}{c}\text { Surface area } \\
\left(\mathrm{m}^{2} / \mathrm{g}\right)\end{array}$ & $\begin{array}{c}\text { Pore volume } \\
\left(\mathrm{cm}^{3} / \mathrm{g}\right)\end{array}$ & $\begin{array}{c}\text { Average pore } \\
\text { diameter }(\mathrm{nm})\end{array}$ \\
\hline CS10 & 562 & 1.20 & 7.6 \\
I-CS10 & 241 & 0.26 & 6.6 \\
CS10-used & 226 & 0.33 & 5.8 \\
I-CS10-used & 144 & 0.18 & 6.9
\end{tabular}


CS10 had a high surface area of about $560 \mathrm{~m}^{2} / \mathrm{g}$. In comparison, I-CS10, prepared by impregnation, had a surface area of about $240 \mathrm{~m}^{2} / \mathrm{g}$, much lower than that of its support $\left(504 \mathrm{~m}^{2} / \mathrm{g}\right.$ ). After the reactions, the surface area of CS10 decreased from 562 to $226 \mathrm{~m}^{2} / \mathrm{g}$, but was still much higher than that of I-CS10 (144 $\left.\mathrm{m}^{2} / \mathrm{g}\right)$.

The $\mathrm{N}_{2}$ adsorption-desorption isotherms and pore-size distribution curves for CS10 before and after sulfidation and reactions are shown in Fig. 3. Both the fresh and used samples exhibited type-IV isotherms [23] with H3 model hysteresis loops, indicating the presence of mainly mesopores. Figure 3(b) shows the corresponding pore-size distribution curves for CS10 and CS10-used. They possessed mainly mesopores, with pore diameters around $3.8 \mathrm{~nm}$.

\subsection{Structural properties of used samples}

Figure 1 shows intense diffraction peaks for $\mathrm{Co}_{3} \mathrm{O}_{4}$ in I-CS10, but no diffraction peaks for Co species were observed for the fresh CS10 sample. After sulfidation and reactions, the $\mathrm{Co}_{3} \mathrm{O}_{4}$ species in I-CS10 were completely converted to $\mathrm{Cog}_{8}$, as shown by the intense diffraction peaks (PDF 75-2023) in Fig. 4. Only traces of diffraction peaks for $\mathrm{Co}_{3} \mathrm{~S}_{4}$ (PDF 75-1561) were observed for the used CS10, again indicating that the Co species were highly dispersed in CS10.

The diffraction peaks were very weak for the used CS10, therefore the extent of sulfidation of this sample had to be con-
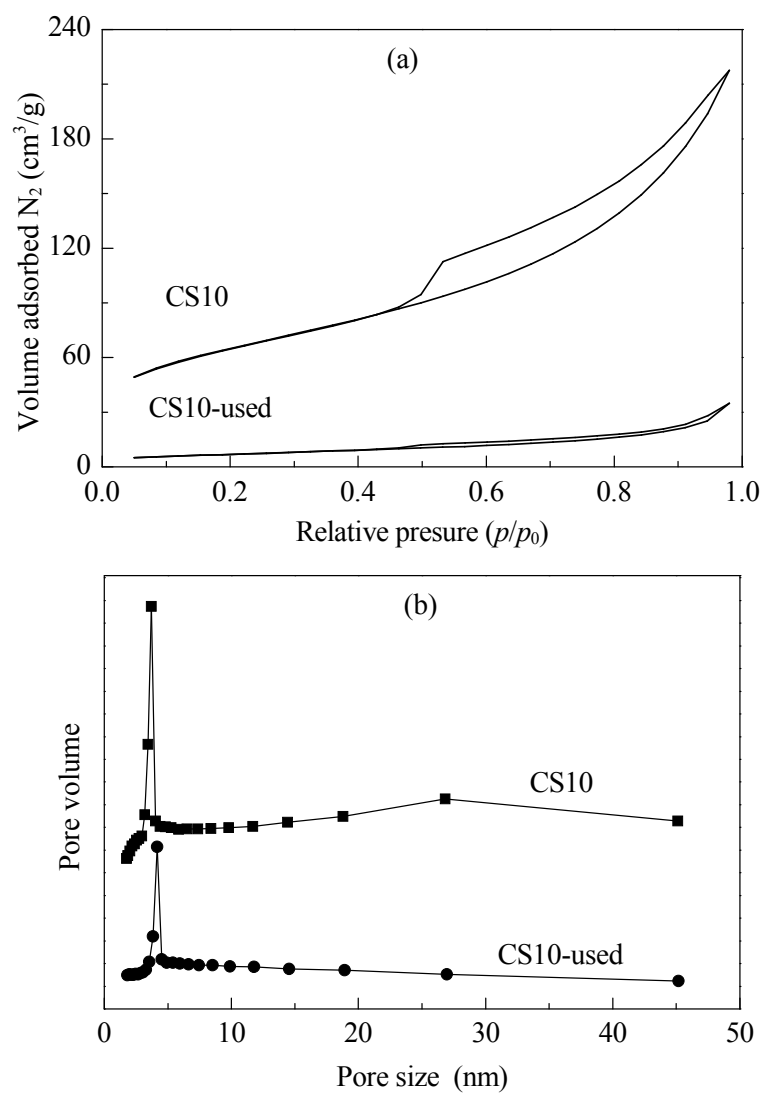

Fig. 3. $\mathrm{N}_{2}$ adsorption-desorption isotherms (a) and corresponding pore-size distributions (b) of CS10 catalyst before and after sulfidation and reactions.

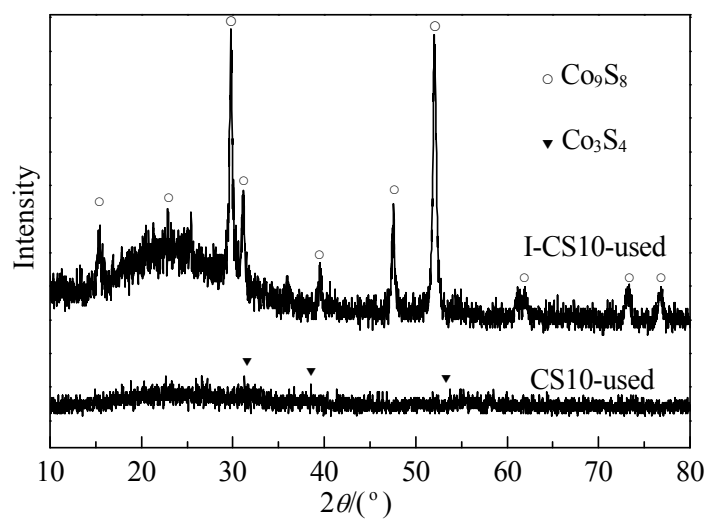

Fig. 4. XRD patterns of CS10 and I-CS10 after sulfidation and reactions.

firmed using another technique; temperature-programmed reduction (TPR) was used, and the results are shown in Fig. 5.

It has been reported that the reduction of unsupported $\mathrm{Co}_{3} \mathrm{O}_{4}$ proceeds through two steps, i.e., $\mathrm{Co}^{3+}$ to $\mathrm{Co}^{2+}$ and then to $\mathrm{Co}^{0}$, in the temperature range 473-673 K [24]. The fresh sample of CS10 displayed two reduction peaks at much higher temperatures $(>900 \mathrm{~K})$, which could be attributed to the reduction of highly dispersed Co cations from $\mathrm{Co}^{3+}$ to $\mathrm{Co}^{2+}$ and then to $\mathrm{Co}^{0}$ species [25]. After sulfidation and reactions, the used CS10 discharged from the reactor might be oxidized in air. The temperatures of the reduction peaks for the used CS10 decreased significantly, to lower than $700 \mathrm{~K}$, compared with those of the fresh samples. These reduction peaks indicated the presence of cobalt sulfides and/or oxides in the used CS10 (oxides could be formed by exposure of the used samples to air). Importantly, these reduction peaks were intense and no reduction peaks appeared at temperatures higher than $750 \mathrm{~K}$, indicating that highly dispersed Co cations, which were difficult to reduce in the fresh sample, were no longer present in the used CS10. In other words, the Co species in CS10 must have been reduced and sulfided during sulfidation and reactions. The XRD patterns and TPR profiles therefore suggest that cobalt sulfide particles must be highly dispersed in the used CS10.

Figure 6 shows scanning electron microscopy (SEM) images of CS10 before and after sulfidation and reactions. Fine parti-

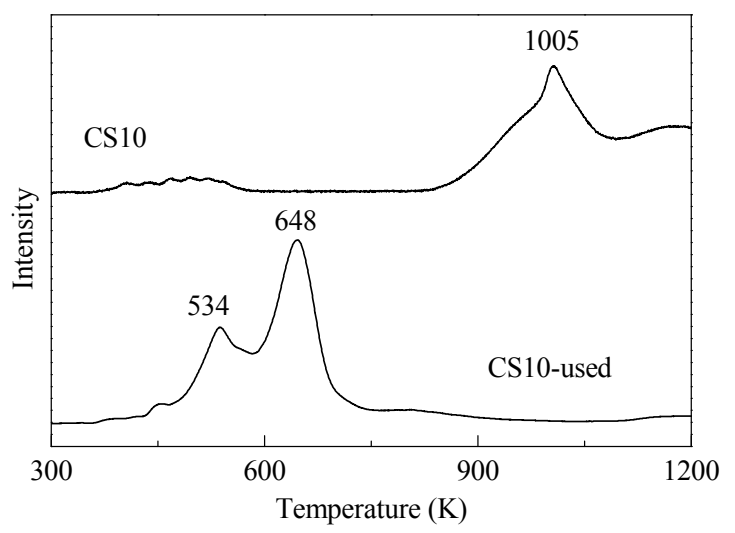

Fig. 5. TPR profiles of CS10 catalyst before and after sulfidation and reactions. 


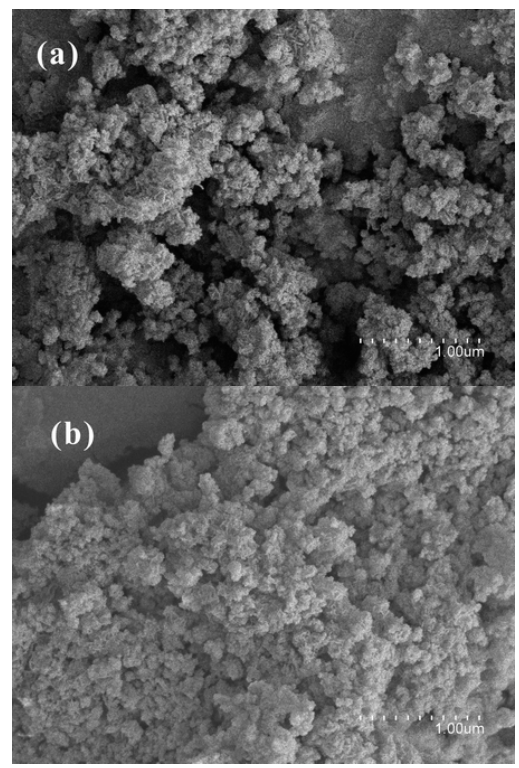

Fig. 6. SEM images of CS10 (a) and CS10-used (b).

cles can be seen for CS10 before and after the reactions. Figure 7 shows transmission electron microscopy (TEM) images for the used CS10 and I-CS10. Some finely dispersed particles with diameters around $2 \mathrm{~nm}$ can be seen in the used CS10, whereas large particles can be observed in the used I-CS10.

\subsection{Surface acidity}

Surface acidities were investigated using microcalorimetric adsorption of $\mathrm{NH}_{3}$ [26]. Figure 8 shows the results for microcalorimetric adsorption of $\mathrm{NH}_{3}$ on $\mathrm{CS} 10$ and I-CS10 before and after sulfidation and reactions. The surface acidity of fresh CS10 was strong, because the initial heat (about $103 \mathrm{~kJ} / \mathrm{mol}$ ) and coverage (about $1144 \mu \mathrm{mol} / \mathrm{g}$ ) were high for $\mathrm{NH}_{3}$ adsorption. After sulfidation and reactions, CS10-used exhibited a lower initial heat $(87 \mathrm{~kJ} / \mathrm{mol})$ and significantly higher coverage (1680 $\mu \mathrm{mol} / \mathrm{g}$ ) for $\mathrm{NH}_{3}$ adsorption. This shows that the surface acidity of CS10-used was also strong, and this might be responsible for

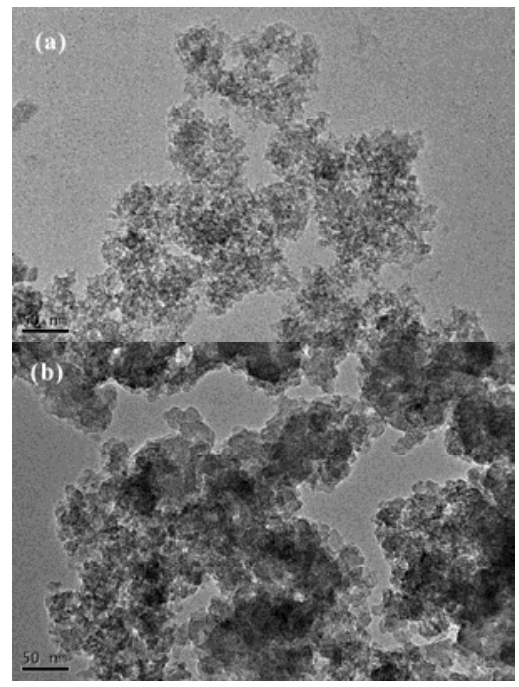

Fig. 7. TEM images of CS10-used (a) and I-CS10-used (b).

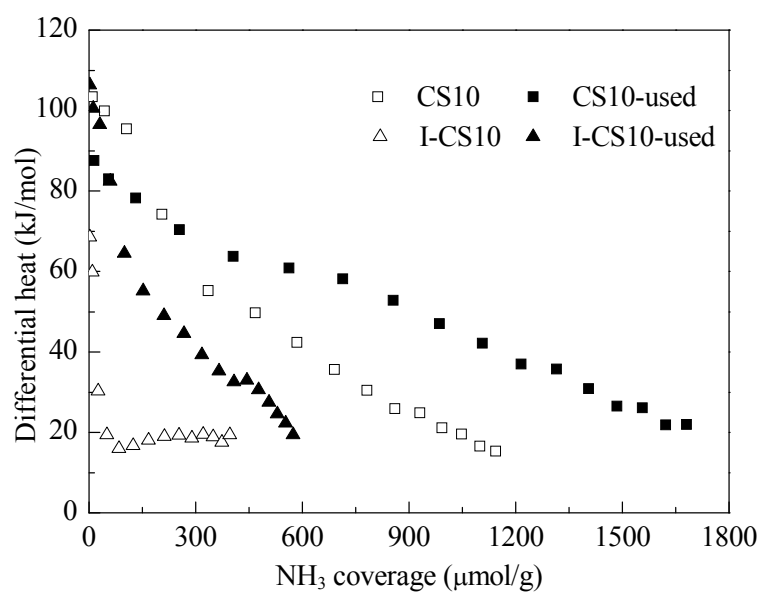

Fig. 8. Microcalorimetric adsorption of $\mathrm{NH}_{3}$ at $423 \mathrm{~K}$ over calcined and used catalysts.

the skeletal isomerization of 1-hexene. The results for the microcalorimetric adsorption of $\mathrm{NH}_{3}$ showed that the surface acidities of I-CS10 and I-CS10-used were much lower than those of their counterparts (CS10 and CS10-used).

\subsection{Isomerization versus hydrogenation of 1-hexene}

The catalysts were sulfided with $\mathrm{CS}_{2}$ (in $n$-heptane) before the reactions. The reactants consisted of 20\% 1-hexene, 500 ppmw thiophene sulfur, and balance $n$-heptane. The HDS of thiophene and conversion of 1-hexene were studied simultaneously. 1-Hexene could be directly hydrogenated to $n$-hexane over the sulfided cobalt, or isomerized to isomers over acidic sites (both skeletal and double bond isomerizations) followed by the hydrogenation to branched and normal hexanes. The direct hydrogenation and skeletal isomerization of 1-hexene were competing reactions, depending on the relative activities of the cobalt sulfides and surface acidity.

Figure 9 shows the conversions of 1-hexene over CS10 and I-CS10 at different temperatures. Both catalysts exhibited high activities for 1-hexene conversion. The conversion of 1-hexene reached nearly $100 \%$ over CS10 at $573 \mathrm{~K}$.

Figure 10 shows the yields of $n$-hexane (the product from

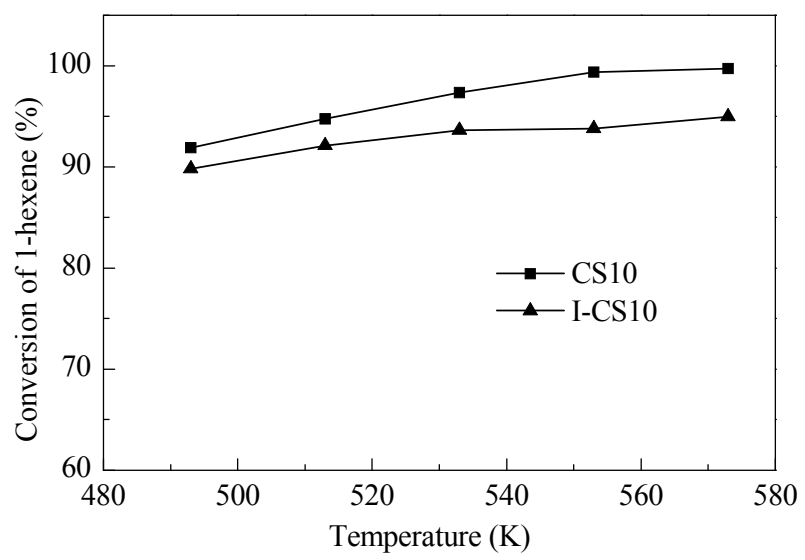

Fig. 9. Conversion of 1-hexene over sulfided catalysts at different temperatures. 

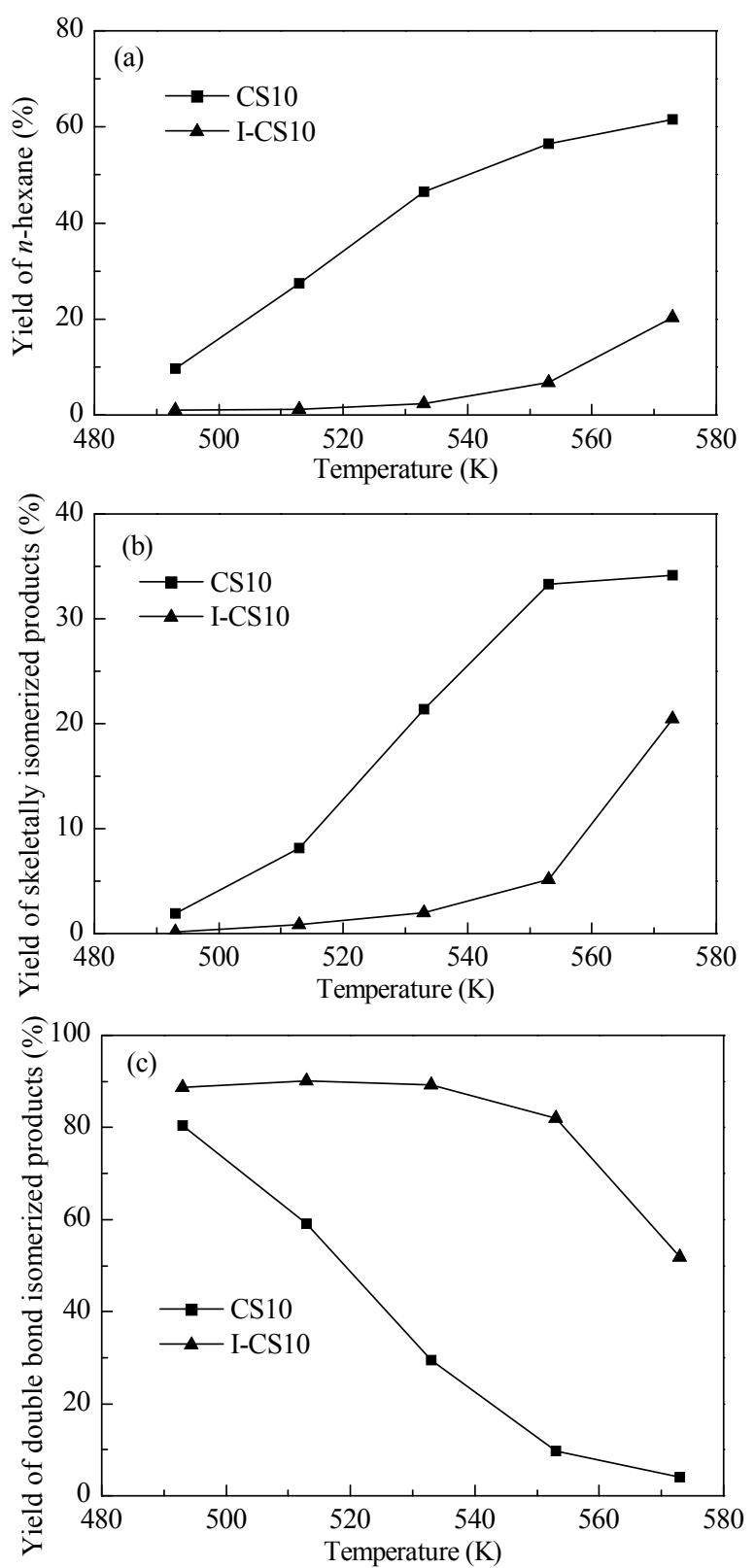

Fig. 10. Yields of products produced by direct hydrogenation (a), skeletal isomerization (b), and double-bond isomerization (c) of 1-hexene over sulfided catalysts at different temperatures.

direct hydrogenation) and isomerization products. It can be seen that the activities of I-CS10 for the direct hydrogenation of 1-hexene and skeletal isomerization were low. This catalyst mainly exhibited selectivity for double-bond isomerization products. The selectivities for directly hydrogenated and skeletally isomerized products were therefore low on this catalyst. The behavior of CS10 in the conversion of 1-hexene was different from that of I-CS10. CS10 exhibited high conversion of 1-hexene $(100 \%)$, high selectivity for $n$-hexane (the direct hydrogenation product; $61 \%$ ), moderate selectivity for the skeletal isomerization products (35\%), and low selectivity for the double-bond isomerization products (4\%) at $573 \mathrm{~K}$.

The XRD patterns showed low dispersion of supported Co in I-CS10, which might account for the low activity for direct hy- drogenation of 1-hexene to hexane on this catalyst. In addition, microcalorimetric adsorption of $\mathrm{NH}_{3}$ indicated that this catalyst had weak surface acidity, which might explain its high activity in double-bond isomerization, but low activity in skeletal isomerization of 1-hexene. In contrast, characterization studies revealed highly dispersed cobalt sulfide and strong surface acidity for CS10, which might be responsible for its high activities in hydrogenation and skeletal isomerization of 1-hexene.

The distribution of products from the conversion of 1-hexene on CS10 at $573 \mathrm{~K}$ is shown in Table 2. It can be seen that about $61.5 \%$ of 1 -hexene was directly hydrogenated to $n$-hexane. The products 2-methylpentane (19\%) and 3methylpentane $(12.9 \%)$ were produced by skeletal isomerization of 1-hexene, followed by hydrogenation to branched alkanes. Other products were various hexenes, including unconverted 1-hexene, and isohexenes produced by double-bond and skeletal isomerization reactions. These hexenes and branched hexanes $(\sim 38.4 \%)$ were valuable compounds with high octane numbers. CS10 could therefore be used for the skeletal isomerization of olefins during the HDS of gasoline, to reduce the octane number loss caused by the simultaneous hydrogenation of olefins.

\subsection{HDS of thiophene}

In industry, HDS of organic sulfur compounds in gasoline is usually carried out on Co-Mo-S catalysts [27], in which Mo is the main active component [28] and Co acts as a promoter. However, it has been reported that Co itself is an active component for HDS reactions if an appropriate method is used for loading Co on a suitable support [29,30,31]. Venezia et al. [29] found that a single-Co catalyst, $5 \% \mathrm{Co} / \mathrm{ASA}$ (ASA = amorphous aluminosilicate), deposited using $\mathrm{Na}_{2} \mathrm{CO}_{3}$, was almost as active as the bimetallic catalyst $1.6 \%$ Co-6.4\% Mo/ASA, prepared by impregnation, for HDS of thiophene.

Figure 11 shows that the conversion of thiophene reached $99.4 \%$ at $573 \mathrm{~K}$ on the sulfided CS10 prepared in this work; conversions of $96.6 \%$ and $95.6 \%$ were achieved industrially on $\mathrm{Co}-\mathrm{Mo} / \gamma-\mathrm{Al}_{2} \mathrm{O}_{3}$ [17] and Co-Mo/MCM-41 [22], respectively, under the same reaction conditions. The single-Co catalyst CS10, without the presence of Mo, was therefore highly active for HDS of thiophene, even more active than traditional Co-Mo-S catalysts. This might be because CS10 (Co-O-Si) simultaneously has a high Co content and high surface area. Moreover, the catalyst exhibited high activity for the skeletal isom-

Table 2

Distribution of products from isomerization of 1-hexene over sulfided CS10 at $573 \mathrm{~K}$.

\begin{tabular}{lc}
\hline Product & Content (wt\%) \\
\hline 1-Hexene & 0.3 \\
n-Hexane & 61.5 \\
2-Methyl-pentane & 19.0 \\
3-Methyl-pentane & 12.9 \\
2-Hexene (cis- + trans-) & 3.1 \\
3-Hexene (cis- + trans-) & 0.9 \\
2-Methyl-2-pentene & 0.8 \\
3-Methyl-1-pentene & 1.1 \\
trans-3-Methyl-2-pentene & 0.3 \\
\hline
\end{tabular}




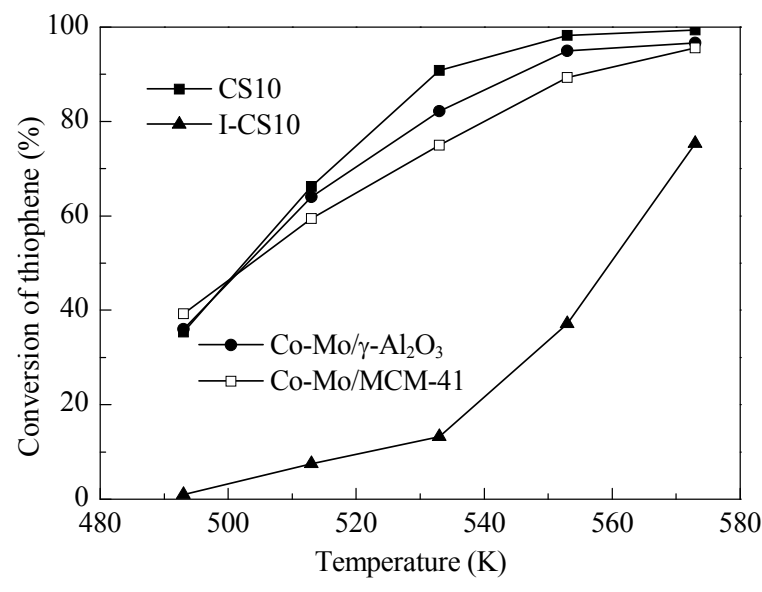

Fig. 11. HDS of thiophene over sulfided CS10, I-CS10, and previously reported $[17,22]$ Co-Mo-S catalysts at different temperatures.

Table 3

Results for skeletal isomerization of 1-hexene and HDS of thiophene over different catalysts.

\begin{tabular}{lcc}
\hline Catalyst & $\begin{array}{c}\text { Yield of skeletally } \\
\text { isomerized products (\%) }\end{array}$ & $\begin{array}{c}\text { Conversion of } \\
\text { thiophene (HDS) (\%) }\end{array}$ \\
\hline $\mathrm{CS} 10$ & 35 & 99.4 \\
$\mathrm{Co}-\mathrm{Mo} / \gamma-\mathrm{Al}_{2} \mathrm{O}_{3}[17]$ & 2 & 96.6 \\
Co-Mo/MCM-41 [22] & 54 & 95.6
\end{tabular}

Reaction conditions: $P=1.5 \mathrm{MPa}, T=573 \mathrm{~K}, \mathrm{LHSV}=2 \mathrm{~h}^{-1}, \mathrm{H}_{2} /$ liquid feed $=300(\mathrm{v} / \mathrm{v})$.

erization of 1-hexene. The yield of skeletally isomerized products from 1-hexene reached $35 \%$ at $573 \mathrm{~K}$ on the catalyst, which was much higher than that (2\%) on industrial $\mathrm{Co}-\mathrm{Mo} / \gamma-\mathrm{Al}_{2} \mathrm{O}_{3}$, but lower than that (54\%) on Co-Mo/MCM-41 (Table 3). However, the Co-Mo/MCM-41 contains Mo, and the synthesis of MCM-41 needs a template and is therefore costly. In contrast, the Co-O-Si catalyst (CS10) was easily synthesized, without the use of a template, and contained only Co as the active component.

\section{Conclusions}

The coprecipitation of sodium silicate with cobalt nitrate, combined with an $n$-butanol drying process, led to the formation of a Co-O-Si complex material (CS10) with a high surface area of about $560 \mathrm{~m}^{2} / \mathrm{g}$. The complex consisted of atomically mixed Co-O-Si networks with high Co contents ( $\sim 34 \mathrm{wt} \%)$ and strong surface acidity. In contrast, a sample (I-CS10) with a similar Co content prepared by impregnation had a significantly lower surface area and weaker surface acidity.

XRD and TPR showed that after sulfidation with $\mathrm{CS}_{2}$, the Co in the CS10 framework was converted to cobalt sulfide $\left(\mathrm{Co}_{3} \mathrm{~S}_{4}\right)$. The cobalt sulfide was highly dispersed on the surface and exhibited high activity for HDS of thiophene and direct hydrogenation of 1-hexene to $n$-hexane. In addition, CS10 had strong surface acidity, and therefore catalyzed the skeletal isomerization of 1-hexene with $35 \%$ selectivity. In contrast, the Co in $\mathrm{CoO}_{x} / \mathrm{SiO}_{2}$ (I-CS10), prepared by impregnation, was converted to $\mathrm{Co}_{9} \mathrm{~S}_{8}$, which was poorly dispersed on the surface, and dis- played low activity in HDS of thiophene and direct hydrogenation of 1-hexene. In addition, the sulfided I-CS10 had low surface acidity and therefore low activity in the skeletal isomerization of 1-hexene. Double-bond isomerizations of 1-hexene were the main reactions on sulfided I-CS10. The CS10 prepared in this work exhibited high activity in HDS of thiophene, compared with industrial $\mathrm{Co}-\mathrm{Mo} / \gamma-\mathrm{Al}_{2} \mathrm{O}_{3}$ and recently reported Co-Mo/MCM-41 catalysts.

CS10 is therefore a precursor of an excellent sulfided catalyst for HDS of thiophene and skeletal isomerization of 1-hexene, even without the presence of Mo. The highly dispersed cobalt sulfide plays a bifunctional role in hydrogenation reactions and skeletal isomerization of olefins. Sulfided Co-O-Si could therefore be used for the skeletal isomerization of linear olefins during deep HDS of organic sulfur compounds in gasoline, so that the octane number losses caused by saturation of olefins could be reduced.

\section{References}

[1] Shen Y T, Shuai S J, Wang H X, Xiao H H. J Environ Sci-China, 2009, 21: 1208

[2] Li D D, Li M F, Chu Y, Nie H, Shi Y H. Catal Today, 2003, 81: 65

[3] Shen J Y, Shi G J. Petrochem Technol (沈俭一, 石国军. 石油化工), 2008, 37: 1111

[4] van Wezel A, Puijker L, Vink C, Versteegh A, Voogt P. Chemosphere, 2009, 76: 672

[5] Maurer T, Kraushaar-Czarnetzki B. J Catal, 1999, 187: 202

[6] Meriaudeau P, Naccache C. Adv Catal, 1999, 44: 505

[7] Ivanov A V, Zausa E, Taarit Y B, Essayem N. Appl Catal A, 2003, 256: 225

[8] Botella P, Corma A, Lopez Nieto J M, Valencia S, Lucas M E, Sergio M. Appl Catal A, 2000, 203: 251

[9] Abbot J, Wojciechowski B W. Can J Chem Eng, 1988, 66: 817

[10] Gee J C, Prampin D S. Appl Catal A, 2009, 360: 71

[11] Lopez C M, Ramirez L, Sazo V, Escobar V. Appl Catal A, 2008, 340: 1

[12] Li H F, Li M F, Chu Y, Nie H. Microporous Mesoporous Mater, 2009, 117: 635

[13] Lee Y, Park M B, Kim P S, Vicente A, Fernandez C, Nam I S, Hong S B, ACS Catal, 2013, 3: 617

[14] Coleto I, Roldan R, Jimenez-Sanchidrian C, Gomez J P, RomeroSalguero F J. Catal Today, 2010, 149: 275

[15] Rao Y, Kang J, Antonelli D M. J Am Chem Soc, 2008, 130: 394

[16] Rao Y, Kang J, Trudeau M, Antonelli D M. J Catal, 2009, 266: 1

[17] Shi G J, Shen J Y. Energ Fuel, 2009, 23: 320

[18] Beck J S, Vartuli J C, Roth W J, Leonowicz M E, Kresge C T, Schmitt K D, Chu C T, Olson D H, Sheppard E W, McCullen S B, Higgins J B, Schlenker J L. J Am Chem Soc, 1992, 114: 10834

[19] Tang N J, Zhong W, Wu X L, Jiang H Y, Liu W, Du Y W. Mater Lett, 2005, 59: 1723

[20] Kiss G, Kliewer C E, DeMartin G J, Culross C C, Baumgartner J E. J Catal, 2003, 217: 127

[21] Yang S F, Liang C H, Prins R. J Catal, 2006, 237: 118

[22] Shi G J, Fang D M, Shen J Y. Microporous Mesoporous Mater, 2009, 120: 339

[23] Springuel-Huet M A, Bonardet J L, Gedeon A, Yue Y, Romannikov V N, Fraissard J. Microporous Mesoporous Mater, 2001, 44-45: 775

[24] Chin R L, Hercules D M.J Phys Chem, 1982, 86: 3079

[25] Jacobs G, Das T K, Zhang Y, Li J L, Racoillet G, Davis B H. Appl Catal 


\title{
Graphical Abstract
}

Chin. J. Catal., 2014, 35: 1402-1409 doi: 10.1016/S1872-2067(14)60074-7

Synthesis of high-surface-area Co-0-Si complex oxide for skeletal isomerization of 1-hexene and hydrodesulfurization of thiophene

Yu Zhao, Jun'en Wang, Hui Chen, Xiaoyan Zhang, Yuchuan Fu*, Jianyi Shen*

Nanjing University

A Co-O-Si complex oxide containing 34 wt\% Co was prepared by coprecipitation of $\mathrm{Na}_{2} \mathrm{SiO}_{3}$ and $\mathrm{Co}\left(\mathrm{NO}_{3}\right)_{2}$. It had a high surface area (562 $\mathrm{m}^{2} / \mathrm{g}$ ), with highly dispersed Co and Si. After sulfidation, the catalyst (CS10) exhibited high activity in hydrodesulfurization (HDS) of thiophene $(99.4 \%)$ and skeletal isomerization of 1-hexene (35\%) at $573 \mathrm{~K}$. It could therefore be used for the skeletal isomerization of linear olefins during deep HDS of gasoline, to reduce octane number loss caused by saturation of olefins.

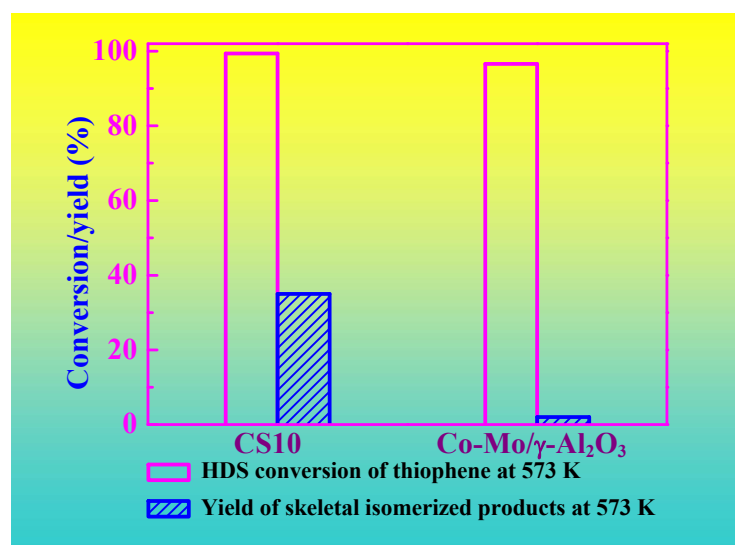

\section{A, 2002, 233: 263}

[26] Cherifi O, Bettahar M M, Auroux A. Thermochim Acta, 1997, 306: 131

[27] Guo C L, Wu Y Y, Wang X, Yang B. J Energy Chem, 2013, 22: 517

[28] Shi G, Han W, Yuan P, Fan Y, Bao X J. Chin J Catal (石冈, 韩伟, 袁 珮, 范显, 鲍晓军. 催化学报), 2013, 34: 659
[29] Venezia A M, Murania R, Pantaleo G, Deganello G. J Mol Catal A, 2007, 271: 238

[30] Venezia A M, Murania R, Pantaleo G, La Parola V, Scire S, Deganello G. Appl Catal A, 2009, 353: 296

[31] Crajé M W J, de Beer V H J, van Veen J A R, vander Kraan A M. Appl Catal A, 1993, 100: 97

\section{高表面积复合氧化物Co-O-Si的制备及其催化1-己烯骨架异构和噻吩加氢脱硫活性}

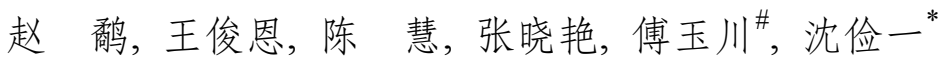 \\ 南京大学化学化工学院介观化学教育部重点实验室, 江苏南京210093
}

摘要: 通过硝酸钴与硅酸钠共沉淀、辅以正丁醇干燥技术制备了具有原子分散度的 $\mathrm{Co}-\mathrm{O}-\mathrm{Si}$ 复合氧化物 $(\mathrm{Co} / \mathrm{Si}$ 原子比 $\approx 0.65)$, 该催 化剂具有较大的比表面积 $\left(562 \mathrm{~m}^{2} / \mathrm{g}\right)$ 和较强表面酸性. 在硫化处理后, 能够形成高度分散的硫化物活性组分, 在模型汽油加氢处理 反应中显示了较高的催化活性, 在 $573 \mathrm{~K}$ 时, 噻吩的加氢脱硫活性可达 $99.4 \%$, 同时, 1-已烯的骨架异构收率达到了 $35 \%$. 该催化剂 虽然不含 $\mathrm{Mo}$, 其加氢脱硫活性可与工业催化剂 $\mathrm{Co}-\mathrm{Mo} / \gamma-\mathrm{Al}_{2} \mathrm{O}_{3}$ 相当. 而在汽油深度加氢脱硫过程中, 直链烯烃往往被加氢饱和, 造 成辛烷值损失. 该催化剂则可使部分直链烯烃发生骨架异构而生成异构烷烃, 可减少深度加氢脱硫过程中的辛烷值损失.

关键词: Co-O-Si复合氧化物; 表面酸性; 加氢; 骨架异构; 加氢脱硫

收稿日期: 2014-01-19. 接受日期: 2014-03-10. 出版日期: 2014-08-20.

*通讯联系人. 电话/传真: (025)83594305; 电子信箱: jyshen@nju.edu.cn

\#通讯联系人. 电话: (025)83594305; 电子信箱: ycfu@nju.edu.cn

基金来源：国家自然科学基金(21273105，21073089); 科技部创新基金(2013AA031703); 中央高校基本科研业务费专项资金 (1084020501).

本文的英文电子版由Elsevier出版社在ScienceDirect上出版(http://www.sciencedirect.com/science/journal/18722067). 